Annals of Warsaw University of Life Sciences - SGGW

Land Reclamation No 46 (3), 2014: 167-179

(Ann. Warsaw Univ. of Life Sci. - SGGW, Land Reclam. 46 (3), 2014)

\title{
Integrated Drought Management Programme in Central and Eastern Europe (IDMP CEE)
}

\author{
JANUSZ KINDLER ${ }^{1}$, TOMASZ OKRUSZKO ${ }^{2}$ \\ ${ }^{1}$ Faculty of Environmental Engineering, Warsaw University of Technology \\ ${ }^{2}$ Department of Water Engineering, Warsaw University of Life Sciences - SGGW
}

\begin{abstract}
Integrated Drought Management Programme in Central and Eastern Europe (IDMP $C E E$ ). The Central and Eastern Europe (CEE) is one of the European regions seriously vulnerable to drought events and there is an urgent need in the region to develop better drought management systems. In February 2013 the Global Water Partnership for Central and Eastern Europe region launched the Integrated Drought Management Programme (IDMP CEE) involving more than 40 organizations from 10 CEE countries. The Programme is structured to provide both policy advice and practical solutions in drought management. The specific objectives of the IDMP CEE are to develop understanding, knowledge and planning for integrated drought management, map and assess the impact of droughts. Moreover, several case studies (demonstration projects) in pilot basins involving local communities are initiated. The national governments are supported to incorporate drought management in their national programs, develop monitoring framework and raise drought awareness through efficient dissemination mechanisms. All countries of the CEE region need to improve both their short-term and long-term responses across sectors to meteorological, agricultural and hydrological droughts. In spite of the fact that several basins in the region are of transboundary character, regional integration of drought monitoring and early warning is not at the level desired. Whilst the lack of water is the primary cause of drought, there are still a large number of factors which exacerbate and intensify its effects. If these factors - many of which have little to do with water per se - are adequately managed, the consequences of the lack of water can be greatly reduced. For example, there are several specific problems and challenges related to the current process of economic transition in
\end{abstract}

the region, including macroeconomic and financial problems.

Key words: drought, risk, management, integration, vulnerability, resilience

\section{INTRODUCTION}

Over the past 30 years, Europe has been affected by a number of major droughts, most notably in 1989, 1991, 2003 and 2005 when overall EU cereal yields were reduced by about $10 \%$ (EEA 2008). However, there is no conclusive proof of a general increase in summer dryness in Europe over the past 50 years due to reduced summer moisture availability (van der Schrier et al. 2006). Despite the absence of a general trend concerning droughts in Europe, there have been distinct regional differences. In particular, more severe river flow droughts have been observed in Spain, the eastern part of Eastern Europe and large parts of the United Kingdom (Hisdale et al. 2001).

More recently (European Commission 2012), it was reported that the number of people and areas hit by drought increased between 1976 and 2006 by almost $20 \%$. The same source reports that the total drought losses over the EU in the past 30 years are estimated to be in the range of 100 billion euro. 
Following the US National Drought Mitigation Center (NDMC 2014), in the most general sense drought originates from a deficiency of precipitation over an extended period of time, resulting in a water shortage for some activity group or for environmental sector. However, drought cannot be viewed solely as a physical phenomenon - its impact result from the interplay between natural event (low or no precipitation for a long time) and the demand people and/or environment place on water supply. In agriculture drought is usually termed as a "difference between precipitation and potental evapotranspiration". But there is no single definition of drought that works in all circumstances. This is one of the main causes that policy makers sometimes have interpretation problems in planning for drought management.

Drought is recognized as a creeping natural hazard and there is no clear understanding of the onset of drought, its termination, and generally accepted techniques to measure its severity and spatial extent. Coping with drought using traditionally accepted measures is clearly not enough to avoid increasingly severe drought impacts. The impacts of droughts spread well beyond agriculture. As demand for water increases, periods of water shortages resulting from extended periods of deficient precipitation and high temperature often results in serious impacts on sectors such as energy, tourism and recreation, transportation, health, and ecosystem services. The socio-economic effects of drought occur at the local level but ripple through the economy to the national and regional levels (WMO/GWP 2011).
The increasingly variable climate in Europe has seen rising numbers of extreme hydrologic events in the last decades, in the Danube, Odra and Elbe river basins just to name a few. Those events pose great challenges to the National Meteorological and Hydrological Services, the Emergency Services and local communities, in the area of flood and drought forecasting, warning emergency preparedness and response.

The WMO and GWP have responded to these challenges first by establishing the Associated Programme on Flood Management (APFM) advocating an integrated approach to flood management embedded in the context of integrated water resources management. In the GWP region of Central and Eastern Europe (GWP CEE), special emphasis has been placed within APFM on a pilot project with a particular view to deadly floods with short lead times - flash floods (APFM 2007). But the CEE region (Fig. 1) is also one of the European regions seriously vulnerable to drought events - for example see the most recent study by Forzieri et al. (2014). Thus, next step taken by GWP CEE was establishment in of the regional Integrated Drought Management Programme (IDMP CEE) within the framework of a global WMO/GWP Integrated Drought Management Programme.

The scope of the global Programme (WMO/GWP 2011) is "to support stakeholders at all levels by providing them with policy and management guidance through globally coordinated generation of scientific information and sharing best practices and knowledge for integrated drought management". The GWP is responding to the drought and climate 
The GWP CEE region

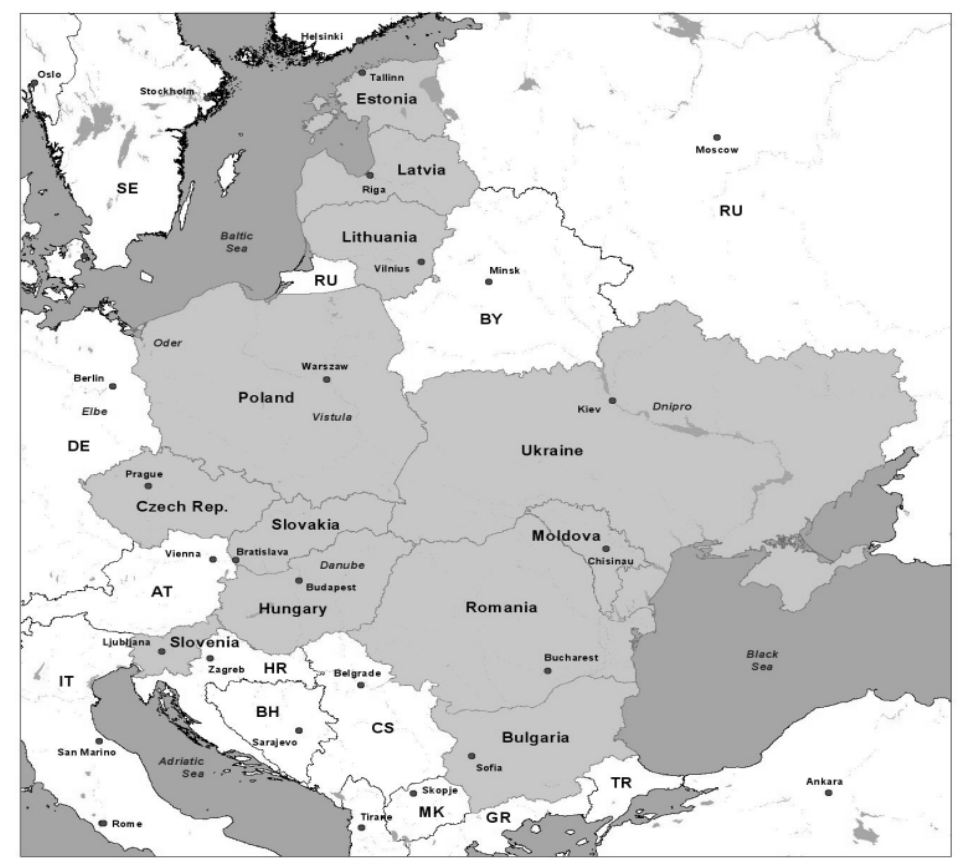

FIGURE 1. The GWP Central and Eastern Europe Region

change challenges through the GWP Global Water and Climate Programme (WCP) which includes a portfolio of programs and projects that aim to build climate resilience through better water management. The WCP also contributes to achievement of the objectives of the United Nations Framwork Convention on Climate Change (UNFCCC) and national adaptation planning (NAP) process.

As vulnerablity to drought has increased, greater attention has been directed to reducing risks associated with its occurrence through introduction of planning to improve operational capabilities and mitigation measures that are aimed at reducing drought impacts. It was more and more realized that the effects of drought require the use of all components of the drought management (Fig. 2), rather than only the crisis management portion of this cycle.

Analyses of drought management practices in many countries today indicate indeed, that decision makers usually react to drought situations through a crisis management approach. This approach to drought management responds to the impacts of drought once it occurs in an attempt to speed up the recovery process. But such an approach has been noted to be expensive, largely untimely, poorly coordinated, and often resulting in resources and assistance being misdirected (WMO/GWP 2011).

While the spatial scope of the WMO/ /GWP Programme is global, the results are expected to be policy relevant and tailored to specific regional and national 


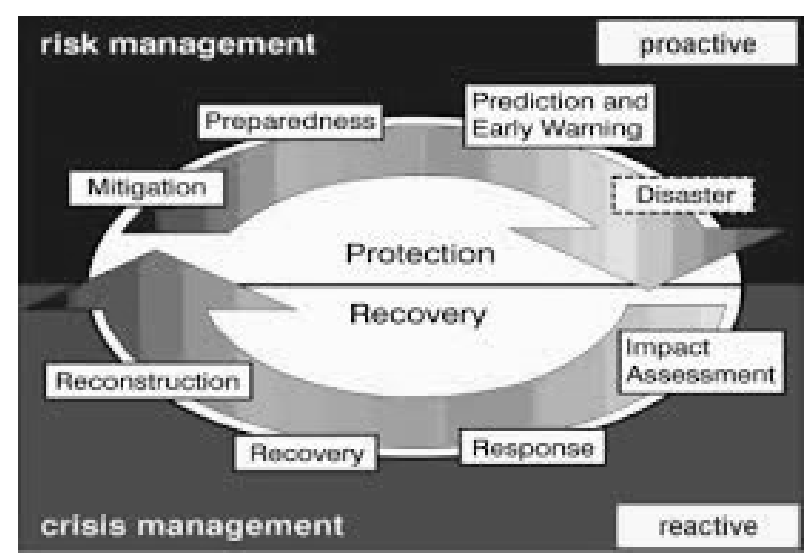

FIGURE 2. The cycle of crisis (drought) management (NDMC 2014)

needs and requirements. The intent is to facilitate partners in various sectors, disciplines, and institutions to provide better drought monitoring and prediction on a regional and national basis, and to use it effectively in the development of short-term and long-term drought management plans and actions. The overarching approach proposed for the Programme centers around four key principles (WMO/GWP 2011):

1. To shift the focus from reactive to proactive and programmatic measures through mitigation, vulnerability reduction and preparedness;

2. To integrate vertical planning and decision-making processes at regional, national and community levels into a framework of horizontally integrated sectors and disciplines (such as water, agriculture, ecosystems and energy);

3. To promote evolution of a knowledge base and establishing mechanisms for sharing it with stakeholders accross sectors at all levels;

4. To build capacity of various stakeholders at different levels.

\section{RATIONALE FOR THE IDMP CEE}

In the past few decades it has become evident that the CEE region is affected by droughts which are becoming more and more lasting and severe. The region's vulnerability to this natural hazard alerted the public, governments, and operational agencies to the many socio-economic problems accompanying water shortage and to the need for drought mitigation measures.

As shown in Figure 3, reduced precipitation, being one of the key phenomena leading to drought, is a recurrent feature of European climate that is not restricted to the Mediterranean. Droughts can occur as well in high and low rainfall areas and in any season (European Environment Agency 2001).

In addition, climate change amplifies the frequency and severity of droughts in the region (Forzieri et al. 2014). The most probable future climate development in the CEE region is directed towards warm and slightly drier summers, warm winters with a rather unchanged average level of annual rainfall and increased frequency of extreme weather 

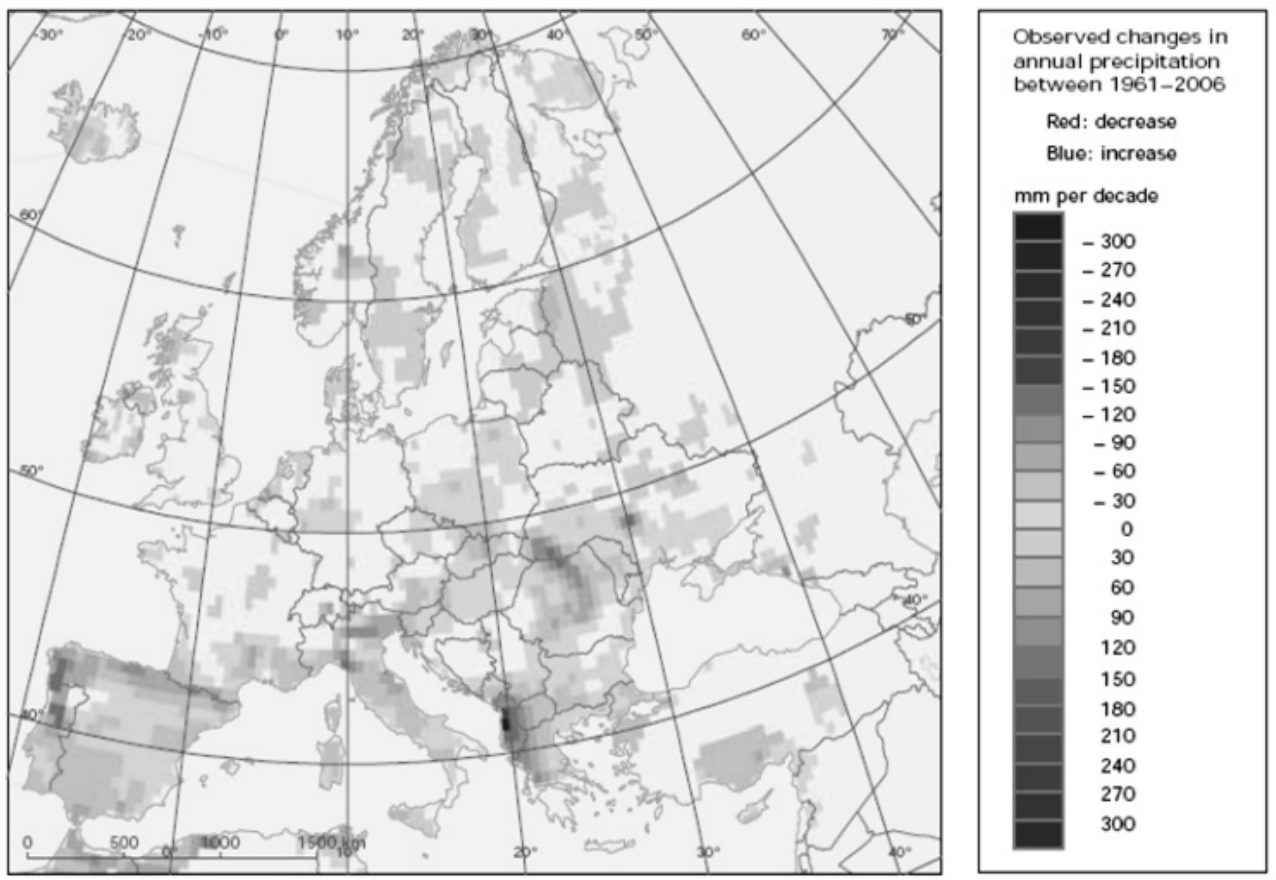

Note:

Data are in $\mathrm{mm}$ per decade, blue means an increase, red a decrease. The observations indicate that large decadal scale variability in precipitation amount is superposed on the long time scale trends described above. This variability is partly related to the decadal scale variability in atmospheric circulation anomalies (see Box 5.1). Calculating trends over shorter time periods may therefore lead to different results.

Source: The climate dataset is from the EU-FP6 project ENSEMBLES (http://www.ensembles-eu.org) and the data providers in the ECA\&D project (http://eca.knmi.nl).

FIGURE 3. Observed changes in annual precipitation over Europe between 1961-2006

events. If these changes persist, they will clearly result in the increase of drought hazards (Fig. 4).

The Regional Council of the GWP CEE initiated the Inception Phase of the IDMP CEE in 2011 by establishing the IDMP CEE Task Force charged with preparation of the Inception Report (mapping study), to provide a review of existing drought risks, policies and strategies in the CEE region. The Inception Phase was important also to map current institutional and legal arrangements regarding drought management. The IDMP Task Force and the GWP Country Partnerships (CWPs) worked together for about 10 months on addressing national and regional drought management challenges. Although most of the countries involved in IDMP CEE are members of the EU, it was found that these countries do not share much information on drought policies and institutional settings, and cooperation in the area of drought management is rather limited.

The Inception Report completed in 2012, consisted of three main sections: (1) Drought situation and the related risks; (2) Mapping current policies regarding drought monitoring and management; (3) National and regional GWP CEE initiatives proposed for IDM 


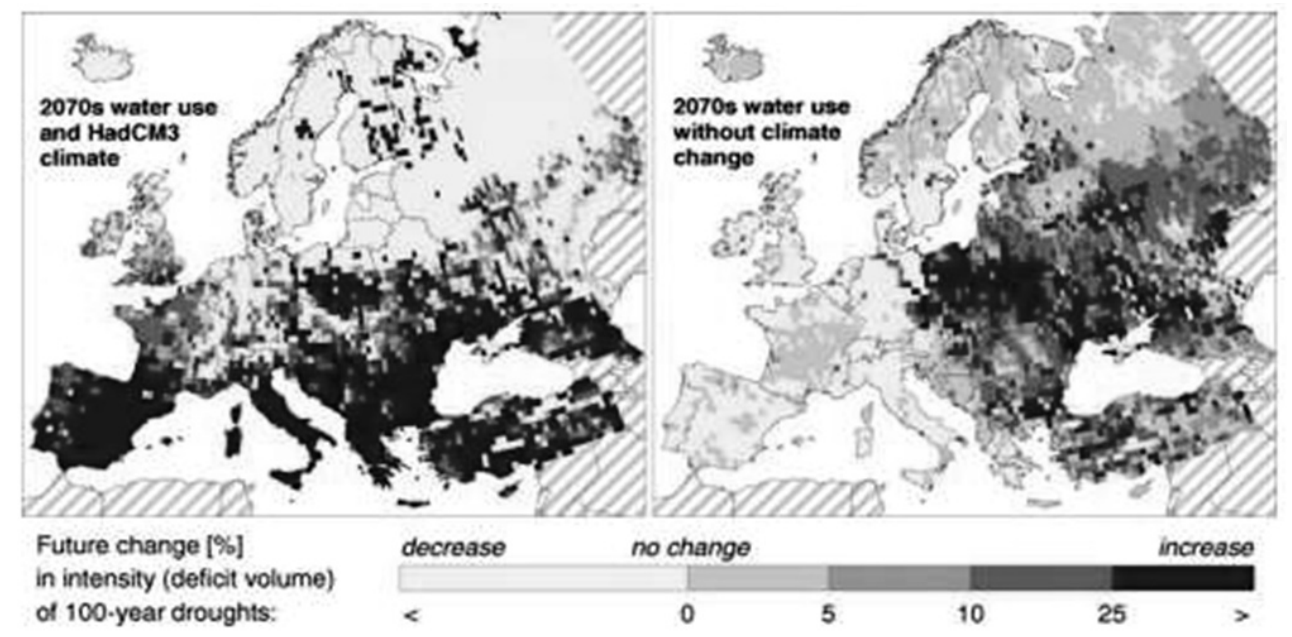

FIGURE 4. Change in recurrence of 100-year drought, based on comparison between today's climate and water use (1961-1990) and simulation for the 2070s models (Lehner et al. 2006)

Programme. The Report also focused on identification of appropriate experts from water and "out-of-water" sectors to contribute to the work of GWP CEE. It should be underlined that the Inception Report was based on information obtained directly from the GWP CEE Country Water Partnerships experts and it represented mostly situation in the specific countries.

The IDMP CEE was launched in February 2013 and involves more than 40 organizations from 10 CEE countries. Going from South to North, these countries are Slovenia, Bulgaria, Romania, Moldova, Hungary, Ukraine, Slovakia, Czech Republic, Poland and Lithuania. The Programme is structured to provide both policy advice and practical solutions in drought management. The value added of this program is that it focuses on integrated approaches rather than fragmented solutions.

The specific objectives of the IDMP CEE are to (Bokal et al. 2014):
- Develop understanding and knowledge and promote state-of-the-art technology, through documentation, consultative workshops, dialogues and networking for integrated draught management;

- Map and assess the impact of droughts, promote the adaptation of best practices, incorporate risk mitigation/reduction and develop drought policies based on scientific knowledge;

- Initiate case studies (demonstration projects) in pilot basins involving local communities;

- Support and facilitate national governments to incorporate assessments on drought management in their national programs and policies;

- Synthesize country findings and develop regional drought policy, including a drought declaration, monitoring framework and a regional drought management platform;

- Raise awareness about severe drought conditions through efficient dissemi- 
nation mechanisms, such as learning platforms, training and workshops/ /seminars.

The proposed activities, including policy advice, aim to increase the resilience of CEE societies to water scarcity and drought events. Consequently, population in drought prone areas and all stakeholders vulnerable to drought are the ultimate target groups for the Programme. At the planning and implementation level, the primary beneficiaries of the Programme are government institutions and agencies responsible for developing drought management policies and/ /or implementing systems for drought monitoring and prediction, drought risk mitigation and response at multiple time and regional, national and local spatial scales. The secondary beneficiaries are decision makers and managers whose task is to implement these policies, including drought mitigation and adaptation. These beneficiaries also include non-governmental institutions involved in regional and national drought advocacy, awareness and response efforts.

\section{COMPONENTS OF THE IDMP CEE}

There are four principal components of the IDMP CEE (Bokal et al. 2014):

- Investments in regional and national development;

- Demonstration projects;

- Knowledge and capacity development;

- Partnerships and sustainability. They are discussed below in more detail.

\section{Investments in regional and national development}

This Program component is designed to advance regional and transboundary cooperation in drought management by integrating water security and drought resilience into national development programs, polices and plans. At the same time the objective is to support regional and transboundary organizations, including the international basin commissions for Danube, Odra, Elbe and Sava rivers, to advance integrated drought management and climate change adaptation in transboundary waters. The current status of implementation of drought management plans and measures within the framework of river basin management plans (according to the EU Water Framework Directive) and other planning documents are being reviewed. Cooperation with/among several regional organizations, such as the UN Convention to Combat Desertification (UNCCD), UN Economic Commission for Europe (UN -ECE), EU Joint Research Centre (EU JRC), Drought Management Centre for Southeastern Europe (DMCSEE), European Drought Observatory and European Drought Center, will be enhanced. Some of the most important activities within this component will also be the establishment of a regional Drought Information Exchange Platform and Drought Helpdesk. The platform shall provide consulting and systems integration services, including innovation workshops on drought risk management tools and drought assessments.

This Programme component is also concerned with the national planning processes. Following the identification 
of drought vulnerable areas in the region and the set of the most appropriate drought indices, a drought mapping exercise will be undertaken with the application of GIS techniques. The regional map will be developed on the basis of separately constructed national drought maps. The objective is to develop Guidelines for drought management planning, which will also serve as a support tool for the preparation of these maps. However, the drought management plans must be prepared with the participation of those who are going to use and apply them - this is the only way to be sure of their practical value. Therefore, the organizing of national consultation dialogues is foreseen. It is envisaged that the consultation dialogues will be coordinated by the appropriate national bodies to ensure government ownership. During the national dialogues, a list of key stakeholders will be developed to whom regular information and output documents will be disseminated. Work on the Guidelines shall last almost for the entire duration of the Programme. In production of the Guidelines, a "bottom-up" approach will be used with the participation of different sectors at different levels and several stakeholders. The main users of the Guidelines will primarily be regional and national entities and individuals who are involved in drought management in each country or river basin, who also participated in the national consultation dialogues. The Guidelines will be the most important product of the IDMP CEE. They will also be used as a training material for training the trainees from all countries involved in the Programme.

\section{Demonstration projects}

The six demonstration projects to be delivered under this component are designed to develop and implement several innovative solutions addressing critical drought management challenges. All of the identified projects are built on the Integrated Water Resources Management (IWRM) and basin plans already in place, or other prioritised projects in development plans. The focus is on areas prone to drought hazards, and finding solutions that will increase resilience and adaptive capacity of the communities. The projects have potential for up-scaling and replication. The projects also range from soft interventions to hard technical solutions that make a real impact on livelihoods, ensuring the building of local adaptive capacity and improving drought resilience. In delivering demonstration projects, special effort will be made to develop partnerships with local institutions that are working at community level, with support and technical assistance from the regional and country teams.

Collecting and analysing data from the demonstration projects will directly contribute to enhancement of knowledge and capacity development. These projects focus on different aspects of drought management to document good practices in application of integrated drought management practices. They are all carefully selected to cover different sectors (water, agriculture, forestry, meteorology) vulnerable to drought impacts (Bokal et al. 2014).

\section{Drought management by agricultural} practices and measures increasing soil water holding capacity. An inventory of soils with different water holding ca- 
pacity will be carried out. This will includes the identification of pilot areas in Slovakia, Poland, Czech Republic and Slovenia, where compacted soils are present. Field experiments will be conducted with the sub-soiling technology and other farming measures (deep root plants cultivation, organic fertilizers use, carbonized biomass use, and others).

Assessment of drought impact on forest ecosystems. Forests significantly depend on the availability of adequate water supplies and at the same time they impact water regime of territories and river basins. After a determination of the vulnerability zones of forest ecosystems and forest life zones in drought situations, the key objective of the project is the identification of mitigation and adaptation measures to be developed for forest ecosystems in Bulgaria, Lithuania, Slovenia and pilot area in Ukraine.

Natural small water retention measures. The so-called "small retention" is an adaptive measure as it serves to adjust to extreme climate variability; specifically, it helps to retain water in the land during wet periods an slows down flood waves during flood periods. Small retention measures include small scale technical and various non-technical activities such as reforestation, the restoration of wetlands, re-meandering of rivers and others. Based on the experience of four CEE countries (Poland, Slovenia, Slovakia and Hungary), the project will demonstrate usefulness of the "small retention" approach.

Drought risk management scheme: a decision support system. This demonstration project aims at developing a framework for an integrated risk management scheme that can be adjusted for a given drought context. Drought information and data will be provided by three project partners (Poland, Romania and Lithuania). The project is consequently oriented to look for measures and methods that constitute a comprehensive, multipurpose and flexible approach that can be detailed and addressed to specific regional purposes. The framework will define the structure of the mapping scheme embodying drought monitoring and forecasting methods, drought assessment and risk analysis procedures as well as drought management strategies to support decision making.

Policy oriented study on remote sensing agricultural drought monitoring methods. Out of the three drought types, namely meteorological, hydrological and agricultural, the latter is the least quantified, and thus the most uncertain drought type. Currently, remote sensing is one of the most important methods for drought warning and measuring, including the forecasting of its effects. The project will focus on elaboration of a monitoring method (with application of remote sensing data), which can result in early warning of drought before irreversible yield loss and/or crop quality degradation occur. The project will use the available database prepared for the Tisza river basin. Alongside Hungary, the two other countries directly involved in the project are Slovakia and Romania.

Upgrading agricultural drought monitoring and forecasting: the case of Ukraine and Moldova. Taking into account current climatic conditions and climate change prospects, this demonstration project is to begin with the revision (upgrading) of the climate zones for the territory of Ukraine and the joint 
Moldova-Ukraine basin of the Dniester river (current zoning established during the Soviet period is obsolete). This work will allow for the identification of drought-prone areas and the development of drought risk maps. In turn, forecasting models for identification of crop yield losses caused by droughts will be developed.

\section{Knowledge and capacity development}

The main objectives of this Program component are to increase capacities and drought related knowledge of water managers together with managers of economic sectors that are vulnerable to drought losses (especially agriculture and public water supply). The most relevant method of capacity development in the CEE region is to organize specialized workshops and capacity building trainings. Organization of four regional workshops for key stakeholders is foreseen and all of them will be concerned especially with development of Guidelines for the national drought management plans. Concerning the capacity building, cooperation with the Cap-Net (international network for capacity building in sustainable water management) will be established. They are developing a special program addressing drought management in the context of IWRM. For participation in regional capacity building trainings ("training the trainers"), two experts from each country participating in the IDMP CEE will be invited. These trainings will next be replicated in the national scale. Finally a manual will be developed in 2015 summarizing experience from all training sessions conducted.
The component is concerned also with knowledge and awareness building. The principal objective is to develop a Compendium of Good Practices in drought management, including a review of drought management projects implemented across all European countries (not only the GWP CEE). The Compendium shall also include the demonstration projects carried out under the IDMP CEE. The overall task of the component is to share knowledge, show how to package and disseminate information and knowledge on design and implementation of drought management, and to raise awareness about the consequences of severe drought conditions. A communication strategy will be elaborated and will include methods and ways of communicating knowledge, increasing public awareness and mobilization of political and governmental authorities. This all will be carried out by publishing articles in the local, national and international news, papers, radio, TV programs and policy briefs.

\section{Partnership and sustainability}

The main objective of this component is to ensure that the network facilitating IDMP CEE is strengthened, as well as to enhance further expansion of programs promoting water security and drought resilience within the framework of sustainable development. It is also concerned with governance of GWP country water partnerships, financial management, stakeholder engagement, project management and work monitoring and evaluation.

The work will focus on building fundraising capacities and governance of the regional water partnerships to be better prepared for new projects. Emphasis 
will also be put on the national partner organizations which should be ready to generate funds as a consortium. It is envisaged, that broad cooperation of stakeholders will result in increased number of organizations that apply for partnership with GWP CEE.

\section{CONCLUDING REMARKS}

The most probable future climate development in CEE is directed towards increased frequency and severity of extreme weather events. If these changes persist, they will clearly result in the increase of drought hazards. Concerning current policies regarding drought monitoring and management, the situation differs considerably in individual countries. The effects of drought are due not only to the physical nature of the hazard, but also to society's ability to manage the associated risks. Drought monitoring, prediction and early warning are not adequate in the region and obviously they need to be improved.

At present, all countries of the CEE region need to improve both their short-term and long-term responses across sectors to meteorological, agricultural and hydrological droughts. Improvements in national and regional frameworks for drought monitoring, early warning and response are needed. In spite of the fact that several basins in the region are of a transboundary character, regional integration of drought monitoring and early warning is not at the level desired. Cooperation on the application of legal and institutional instruments at regional level is significantly behind the work of researchers. A transnational in- tegrated approach is needed for the successful tracking of drought, comparing its impacts using common methodology and assessing vulnerability of various sectors to drought occurrence.

Whilst the lack of water is the primary cause of drought, there are a large number of factors which exacerbate and intensify its effects. If these factors - many of which have little to do with water per se - are adequately managed, the consequences of the lack of water can be greatly reduced. For example, there are several specific problems and challenges related to the current process of economic transition in the region, including macroeconomic and financial problems. Another problem is the use of unsustainable development practices in some drought affected areas as a result of complex interactions among physical, biological, political, social and economic factors.

As pointed out by Bokal et al. (2014), the IDMP CEE will fully observe the IWRM principles which are the cornerstone of all GWP activities. It will strive for the horizontal integration of effort by water specialists working together with those representing meteorological and hydrological services, agriculture and energy sectors, forestry services and others. This is the only way to avoid work fragmentation. At the same time vertical integration of drought management is needed. The management actions have to be coordinated at all scales - regional, national and local. The subsidiary principle that decisions are taken at the lowest level where impact occurs must be respected, but when it comes to drought policy and finance these must be taken at the appropriate higher levels. 


\section{Acknowledgments}

All comments and suggestions made by the Reviewers were gratefully accepted by the authors and the corresponding changes are shown in the final text of the article.

\section{REFERENCES}

APFM 2007. Guidance on Flash Flood Management, Recent Experiences from Central and Eastern Europe. Report by WMO/GWP Associated Programme on Flood Management, December 2007.

BOKAL S., GROBICKI A., KINDLER J., THALMEINETROVA D. 2014. From national to regional plans - the Integrated Drought Management Programme of the Global Water Partnership for Central and Eastern Europe. Weather and Climate Extremes 3, 37-46.

European Commission 2012. Water scarcity and drought - 2012. Policy Review - Building blocks (Non-Paper).

European Environment Agency 2008. Impacts of Europe's changing climate - 2008 indicator-based assessment. Joint EEA-JRC-WHO Report.

FORZIERI G., FEYEN L., ROJAS R., FLORKE M., WIMMER F., BIANCHI A. 2014. Ensemble projections of future streamflow droughts in Europe. Hydrology and Earth System Sciences 18 (1), 85-108.

HISDALE H., STAHL K., TALLAKSEN L.M., DEMUTH S. 2001. Have droughts in Europe become more severe or frequent? International Journal of Climatology 21, 317-333.

LEHNER B., DOLL P., ALCAMO J., HEINRICHS T. KASPAR F. 2006. Estimating the impact of global change on flood and drought risk in Europe: A continental integrated analysis. Climatic Change 75, 273-299.
NDMC 2014. What is drought? The National Drought Mitigation Center. Lincoln - Nebraska, USA.

van der SCHRIER G., BRIFFA K.R., JONES P.D., OSBORN T.J. 2006. Summer moisture availability across Europe. Journal of Climate 19, 2818-2834.

WMO/GWP 2011. Integrated Drought Management Programme. A joint WMOGWP Programme, Concept Note. Version 1.2

Streszczenie: Program Zintegrowanego Zarzqdzania Ryzykiem Suszy $w$ Europie Środkowo-Wschodniej (IDMP CEE). Artykuł jest poświęcony regionalnemu „Programowi Zintegrowanego Zarządzania Ryzykiem Suszy w Europie Środkowo-Wschodniej", realizowanemu przez Globalne Partnerstwo dla Wody - Region Europy Środkowo-Wschodniej (IDMP CEE), w ramach globalnego Programu Zarządzania Ryzykiem Suszy prowadzonego przez Światową Organizację Meteorologiczną (WMO) i Globalne Partnerstwo dla Wody (GWP). Celem Programu WMO/ /GWP jest „,wsparcie zainteresowanych instytucji wszystkich szczebli opracowaniem wytycznych zintegrowanego zarządzania ryzykiem suszy, z wykorzystaniem światowych doświadczeń naukowych i najlepszych doświadczeń w tym zakresie". Program jest ukierunkowany na badania i analizę możliwości planowania i podejmowania zawczasu różnorodnych działań wyprzedzających wystapienie suszy, niezależnie od działań podejmowanych $\mathrm{w}$ trakcie oraz po wystapieniu suszy. W latach 2011-2012, specjalnie powołana międzynarodowa grupa robocza opracowała „Inception Report IDMP CEE” omawiający rodzaje i częstotliwość występowania susz w poszczególnych krajach regionu, obecne zasady i praktyki zarządzania ryzykiem suszy w tych krajach oraz propozycje programowe każdego z 10 narodowych komitetów GWP CEE: Słowenii, Bułgarii, Rumunii, Mołdawii, Ukrainy, Węgier, Słowacji, Polski, Litwy i Republiki Czeskiej. Rozpoczęte w pierwszej połowie 2013 roku prace nad IDMP CEE składają się z czterech głównych komponentów realizowanych przez 40 instytutów oraz innych placówek badawczych z wspomnianych wyżej krajów. Istotnym zadaniem tego pakietu jest budowa platformy informacyjnej ds. suszy 
dla regionu CEE we współpracy z podobną platformą europejską Joint Research Centre Komisji Europejskiej (Ispra). W ramach tego komponentu przewiduje się opracowanie dla krajów CEE wytycznych narodowych planów zarządzania ryzykiem suszy, wykorzystując ustalenia Komisji Europejskiej. Kolejny komponent poświęcony jest sześciu projektom pilotowym realizowanym w grupach międzynarodowych. Projekty te dotyczą problematyki powiększania pojemności retencyjnej gleby, oceny wpływu susz na ekosystemy leśne, małej retencji, systemów wspomagania decyzji w zarządzaniu ryzykiem suszy, wykorzystaniu danych satelitarnych w systemach monitorowania suszy oraz doskonaleniu rolniczych sieci monitoringowych. Pozostałe pakiety dotyczą organizacji spotkań roboczych poświęconych wybranym problemom metodycznym zarządzania ryzykiem suszy, szkoleniom prowadzonym dla całego regionu i w ramach poszczególnych krajów, opracowaniu zarówno kompendium dobrych praktyk, jak i programów dla ludności zamieszkującej regiony zagrożone suszami, wyjaśniających związane z nimi zagrożenia i możliwości zapobie- gania ich skutkom. Przewidywany czas realizacji Programu wynosi 2,5 lat.

Stowa kluczowe: susza, ryzyko, zarządzanie, integracja, narażenie (np. na straty), odporność

MS. received August 2014

Authors' addresses:

Janusz Kindler

Politechnika Warszawska

Wydział Inżynierii Środowiska

ul. Nowowiejska 20

00-653 Warszawa

Poland

e-mail: janusz.kindler@is.pw.edu.pl

Tomasz Okruszko

Wydział Budownictwa i Inżynierii Środowiska

SGGW

Katedra Inżynierii Wodnej

ul. Nowoursynowska 166

02-787 Warszawa

Poland

e-mail: t.okruszko@levis.sggw.pl 